\title{
Portraits of Qing meritorious officers in the collection of the State Hermitage: scroll restoration and revised reading of the texts
}

Abstract: The finished restoration of the portraits representing prominent Qing officers kept in the collection of the State Hermitage resulted in a possibility to not only prove their artistic value, but also to read the eulogies written by Emperor Qianlong in Manchu and Chinese. As a follow-up of our previous paper ${ }^{1}$ we are presently able to become certain that the State Hermitage has five portraits (of Yeotun, Fusil, Cebdenjab, Bolbunca and Guwandase), originally from the Ziguang-ge Pavilion (Hall of Purple Glaze), which made it to Germany in the early 20th c., and then, after 1945, to Russia. The analysis of the texts has revealed the peculiarities of Manchu and Chinese poetry at the same time proving that both versions of the eulogies were written in accordance with corresponding poetic rules thus becoming variations of the same topic.

Key words: portraits of Qianlong meritorious officers, Qianlong's poems, the State Hermitage, the Manchu language, the Chinese language

Our paper "Portraits of meritorious officers from the collection of the State Hermitage museum" published in "Pis'mennye pamiatniki Vostoka", issue 2(15), $2011^{2}$ contained the first ever presentation of four portraits representing four heroes of the Eastern Turkestan raid and painted in 1760 for the Ziguang-ge Pavilion (Hall of Purple Glaze) of the Imperial Palace in Peking. The State Hermitage received these portraits after WWII from the Ethnological Museum in Berlin; for a long time they were kept in a secret storage. The scrolls had been badly damaged during the Berlin battles of 1945, and it was not before 2007 that they got delivered to the Hermitage

(C) Pang Tatiana Alexandrovna, Institute of Oriental Manuscripts

(C) Pchelin Nicholay Georgiyevitch, The State Hermitage Museum

${ }^{1}$ PANG, PCHELIN 2011: 262-278.

${ }^{2}$ PANG, PCHELIN 2011: 262-278. 

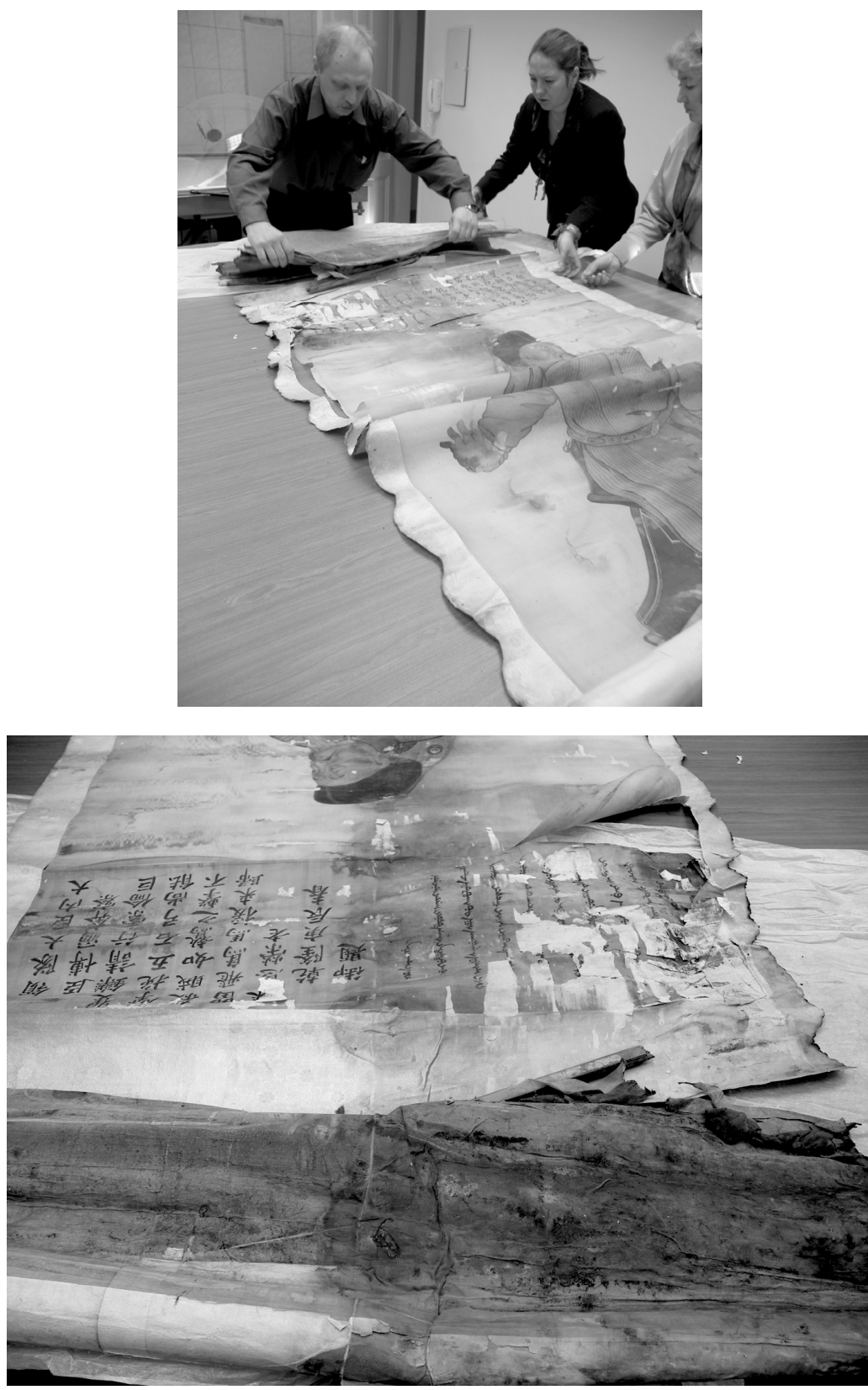

Figs. 1 and 2. Scrolls delivered to the Hermitage laboratory of scholarly restoration of fabrics and watercolors

(C) State Hermitage Museum 

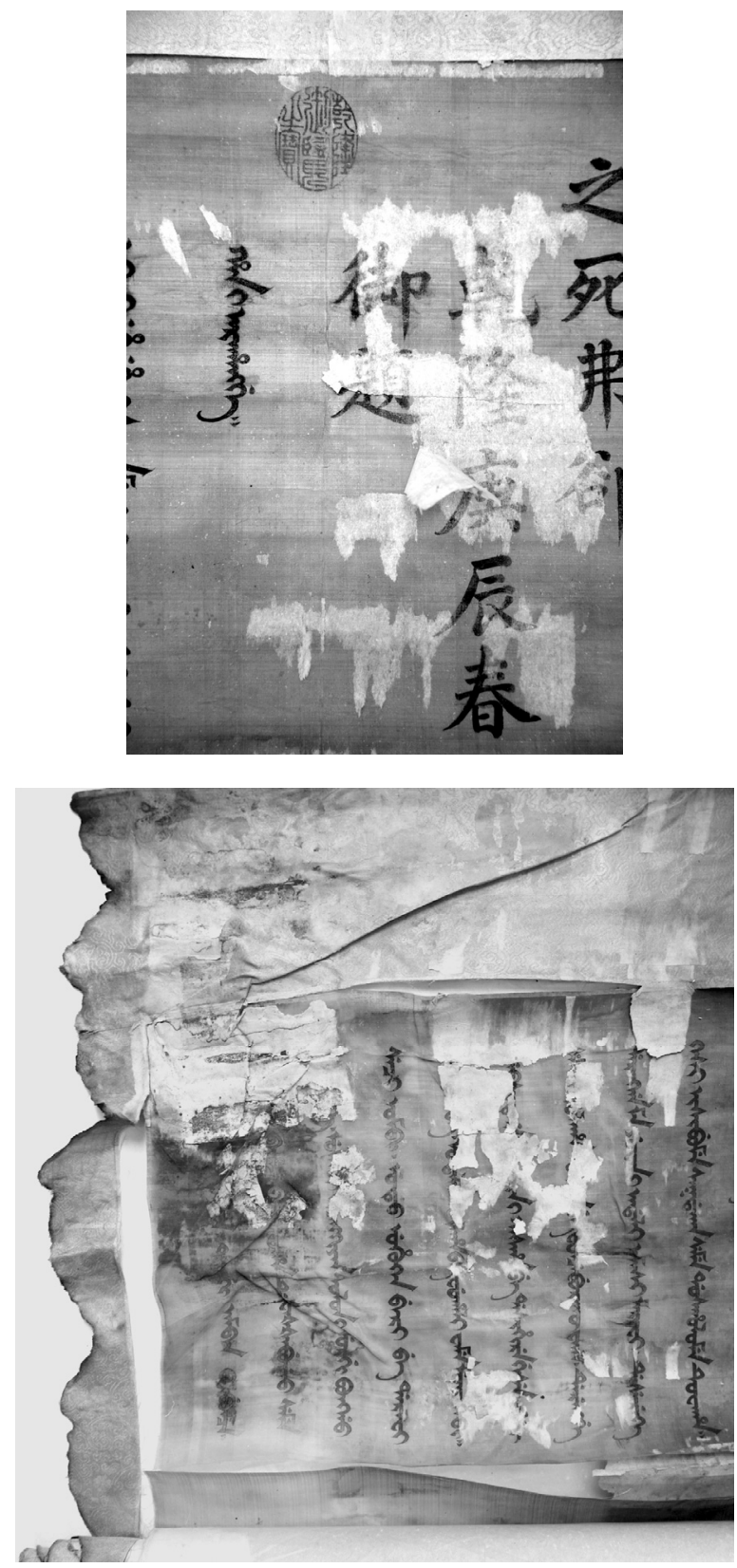

Figs. 3 and 4. The fabric and paper were coated with a layer of starch-based glue, the silk and paper having been strongly destructured and soiled with dust, soot, and ash (C) State Hermitage Museum 


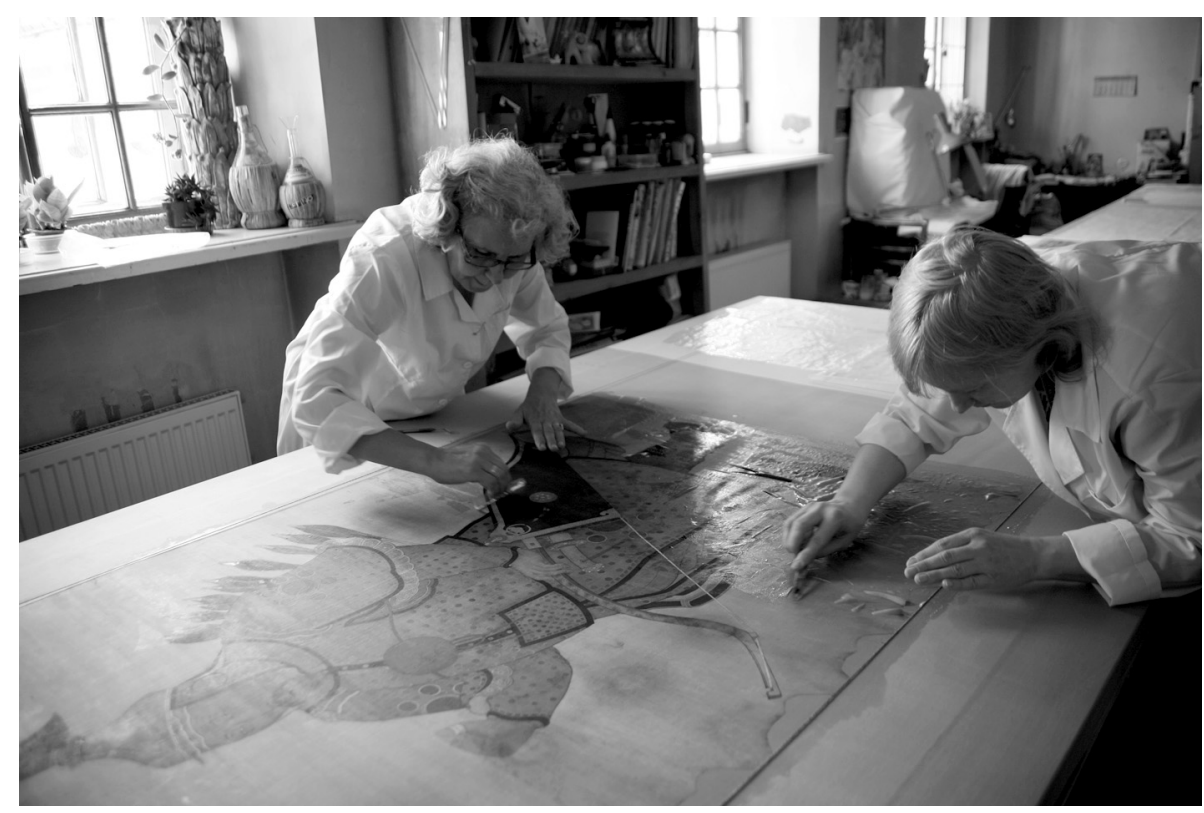

Fig. 5. The process of restoration

(C) State Hermitage Museum

Laboratory of scholarly restoration of fabrics and water colors. At that moment, their condition was described by the experts as follows: the previously restored scrolls had been completely pasted over paper; both the fabric and paper were coated with a layer of starch-based glue, the silk and paper having been strongly destructured and soiled with dust, soot, and ash; their surfaces displayed multiple brown spots and dense rust. The paint was peeling off the over-dry and deformed, partly destroyed silk base; the remaining parts were frayed and torn. The edges were burnt and threadbare.

The complicated and time-consuming restoration of these four scrolls had been conducted in 2007 through 2014 by artists A.F. Alexandrova, L.E. Kovaleva, and N.Yu. Liakina who described the process in the following way: the layer of paint was fixed; the spots of rust were softened with chemicals; all fragments were cleansed with water solvents. After that, all parts of the scrolls got joined anew over a dubbing silk basis, the dirt and pasted-over paper having been removed. The complexity of this work resulted from the fact that the fragments were to be joined from the front side; that required immense care and accuracy, ruling out any possibility of the glue soiling the neighboring parts of painting. The work was considered finished when the 
scrolls were cleaned and dubbed, their deformation removed, and the whole of the original basis, restored.

Yet before the end of restoration works, motivated by the chance to introduce the exhibits from the former German collection, in 2011 we attempted publishing four of these portraits as they were at that time. Then, the Laboratory had seven scrolls, but only five among them portrayed Manchu meritorious officers, and at that moment only four could be unfolded without fear of damaging them. Our reports on the restoration and the value of these portraits have been presented at several international conferences. ${ }^{3}$

Once published, our paper and the work over the portraits caused significant interest of our German colleagues, ${ }^{4}$ which attested of the importance of the artifacts for learning the original compound of the Hall of Purple Glaze, as its collection has by now been scattered all over the world. Meanwhile, the work went on, and the restoration conducted at the State Hermitage resulted in our having not solely the portraits themselves, but also the significantly damaged texts of the eulogies in Manchu and Chinese. Our first paper already contained detailed descriptions of the portraits painted on these four scrolls; we provided information about clothes and uniforms, and attempted to read and interpret legible words and phrases. ${ }^{5}$ Thanks to the restoration, we have managed to read the Manchu and Chinese texts anew, to correct previously made mistakes and to correctly split Manchu lines in accordance with the alliteration of Manchu poetry. ${ }^{6}$

In that, we were assisted by the paper "Die ehemalige Sammlung von Porträts verdienter Offiziere der Feldzüge des Qianlong-Kaiseers (China, 18. Jahrhundert)" by Hartmuth Walravens, ${ }^{7}$ providing descriptions of the scrolls containing the portraits and prior to WWII kept in Berlin, at the Königliches Museum für Völkerkunde, presently the Ethnological Museum and deemed irretrievably lost. That publication is highly valuable, also because it presented archival photographs of 15 portraits (out of 16), among which there are also those presently kept at the State Hermitage.

All portraits are uniformly shaped as vertical scrolls with eulogies in Manchu and Chinese written over them in black ink; between the dates, each one displays a red oval seal reading Qianlong yulan zhi bao 乾隆御覽之寶

\footnotetext{
${ }^{3}$ PANG 2015: 180-181.

${ }^{4}$ WALRAVENS 2013: 125-166; BÜGENER 2015.

${ }^{5}$ PANG, PCHELIN 2011: 267-276.

${ }^{6}$ PANG, PCHELIN 2016: 74-90.

${ }^{7}$ WALRAVENS 2013: 125-166.
} 
"A treasure having the highest approval of Qianlong". The previously published four portraits display dates in Manchu: Abkai wehiyehe-i šanyan muduri aniyai niyengniyeri (the spring of the White Dragon year of Abkai wehiyehe) and Chinese: Qianlong gengchen chun 乾隆庚辰春 (the spring of the gengchen year of Qianlong) which corresponds the year of 1760 . The fifth portrait bears a later date: Abkai wehiyehe-i fulgiyan bonio aniyai niyengniyeri (the spring of the reddish monkey year of Abkai wehiyehe), in Chinese Qianlong bingjia chun 乾隆丙甲春 (the spring of the bingjia year of Qianlong) or 1776. Below the texts, every scroll has the full-length portrait of a chieftain.

Presently we can introduce the texts in full along with their translations. ${ }^{8}$

The eulogy on the first scroll (ref. No. VF 2801) is dedicated to keterkei baturu (outstanding hero) ${ }^{9}$ Yeotun who belonged to the Pure Yellow banner and served in Butha. He is known to have been a marksman who killed a tiger during an Imperial hunting in Mulan. In 1755, he participated in the Eastern Turkestan raid after which was appointed the commanding officer of the Mongolian Boarded White banner in Qiqihar. ${ }^{10}$

The Manchu eulogy is written as two stanzas with initial alliteration, the first one beginning with $i$, the second with $e$. Noteworthy is the fact that the Manchu text provides more information than its Chinese counterpart: it indicates Yeotun's origin in Manchuria, "he hunted near the river Ula". Each line of the Chinese version has four characters with a caesure in the middle;

\footnotetext{
${ }^{8}$ We made our first attempt to analyze poetic peculiarities of Manchurian and Chinese eulogies accompanying these four portraits in our report during the 7th International scholarly conference "Problems of literatures of the Far East" in 2016 (PANG 2016: 473-481).

${ }^{9}$ Hartmuth Walravens suggested translating keterkei baturu as "der Haervorragende Held" (WALRAVENS 2013: 142).

William F. Mayers in his manual of Chinese titles "The Chinese Government" suggests the following explanation of baturu: "The military distinction called in Chinese Pa-t' $u$-lu (a representation of the Manchu word baturu, signifying 'brave') is an institution dating from the early years of the present dynasty, and is conferred solely for active service in the field. It constitutes an order of merit partaking of some characteristics of the French Légion d'honner; but its special feature of difference from a European order consists in the fact that it has no outward mark of decoration to be worn by its possessor, in the place of which there can only be reckoned the distinguishing word (or title) which is assigned to each recipient on the bestowal of the order. These specific titles may be either Manchu, Mongolian, or Chinese, the Manchu being considered the most honourable. Under this system an officer upon whom the distinction is conferred might receive the designation Yih Yung Pa-t'u-lu 毅勇巴圖魯, or "Bat'uru with the title Magnanimous Brave", and so forth. The title carries with it the right to wear the peacock-feather." (MAYERS 1886: 67).

${ }^{10}$ WALRAVENS 2013: 142-144; BÜGENER 2015: 350-352.
} 

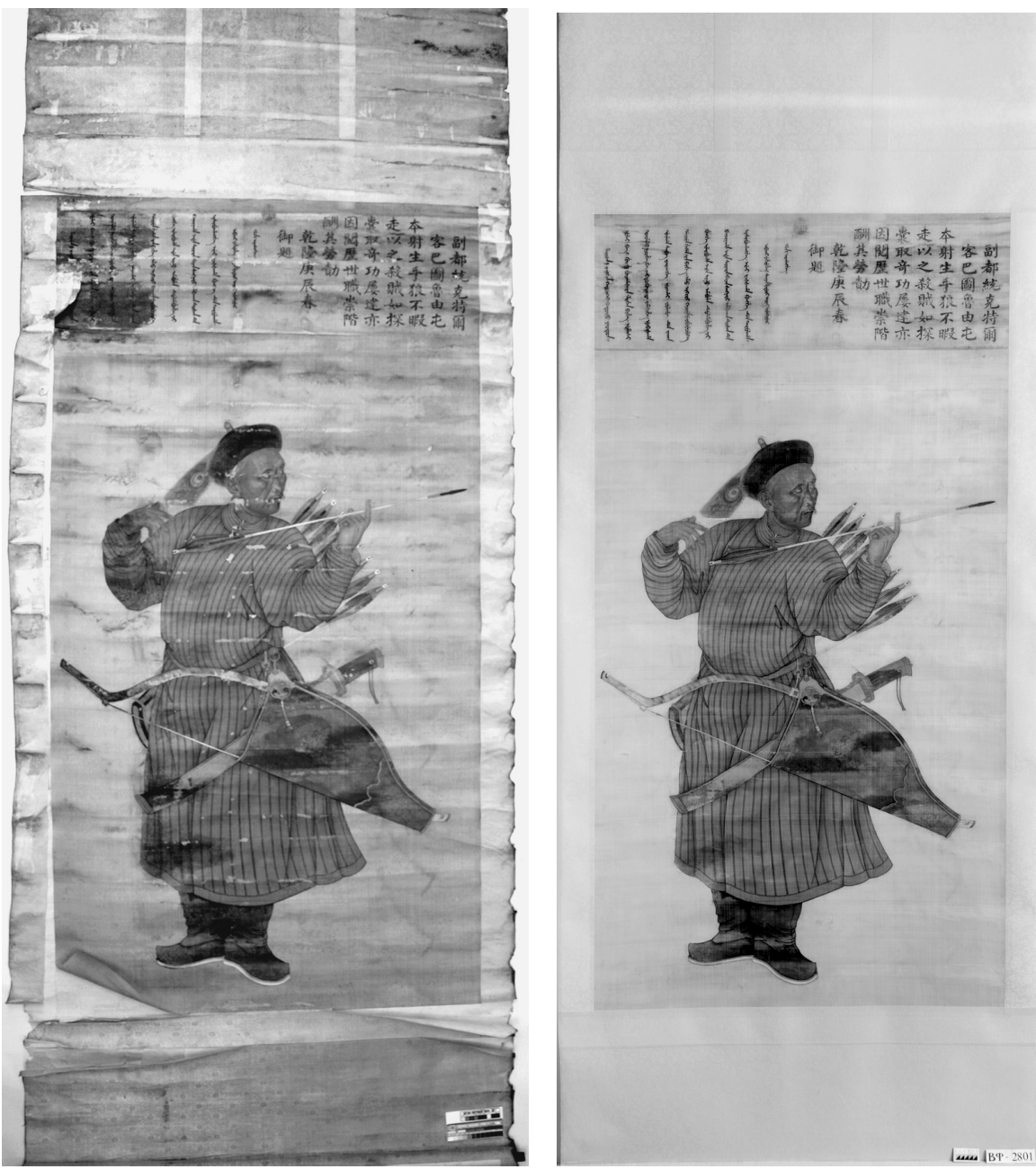

Figs. 6 and 7. Yeotun's portrait before and after the restoration (C) State Hermitage Museum

the eulogy contains references to Chinese classics. For instance, shenshou 生 手 "with bare hands" can be found in the "Tang Anthology" — "Quan Tang shi” 全唐诗 (QTSh, j. 23) and the Song collection "Detailed Chronicles of the Taiping Years" - “Taiping guangji” 太平廣記 (TPGJ, section jing cha 精察, chapter Wei-Xiansheng); the expression tang nang qui 探囊取 “to get into a sack and produce easily" is encountered in the novel "Journey to the West" (XYuJ, ch. 8) and history of "Three Kingdoms" (SGZh, ch. 23); the 
verb yueli 閱歷 “to learn from one's own experience" is there in the "Detailed Chronicles of the Taiping Years" (TPGJ, j. 4); the word shizhi 世職 "a hereditary title" can be found in the Song encyclopedia "Highly Approved Collection of the Taiping Years” “Taiping yuelan”太平御覽 (TPYL, j. 430).

\section{Transliteration of the Manchu text:}

Meiren-i janggin keterkei baturu Yeotun:

ulai ba-i gurgu buthašara mergen bihe.

umesi koimali niohe be jabduburakû wambihe

ubašsaha hûlha sabe warangge.

uthai fulhû de jaka gaire gese ja bihe:

emu ikiri kejine ferguwecuke gungge ilibuha

ere inu ambula dulembuhe ci banjinaha

ede sirara hafan šangnafi ambakan tušan de isibuhangge.

erei faššaha gungge de karulaha

Abkai wehiyehe-i šanyan muduri aniyai

niyengniyeri han-i arahangge
Chinese text:

副都統克特爾客巴圖魯由屯 本射生手

狼不㗇走

以之殺賊

如探囊取

奇功屢建

亦因閱歷

世職崇階

酬其勞勣

乾隆庚辰春御題

\section{Translation from Manchu:}

Flank chieftain keterkei baturu Yeotun expertly hunted wild animals in the Ula, he never got tired of killing ferocious wolves.

He killed traitors and rebels with an equal ease,

as if he put animals into a sack.

He incessantly performed surprising deeds.

He stayed alive after great [trials].

For all that he received a hereditary title and achieved high ranks.

His merits and deeds were rewarded.

Written by the Emperor in the spring of the White Dragon year of Abkai wehiyehe.

\section{Translation from Chinese:}

Futudun keterkei baturu Yeotun

He hunted with bare hands,

A wolf could not escape [him].

He also killed traitors,

As if putting them into a sack.

He frequently performed outstanding deeds

And he learned everything from his own experience.

He glorified his clan with a hereditary title,

And his merits and deeds were rewarded.

Written by the Emperor in the spring of the gengchen year of Qianlong. 

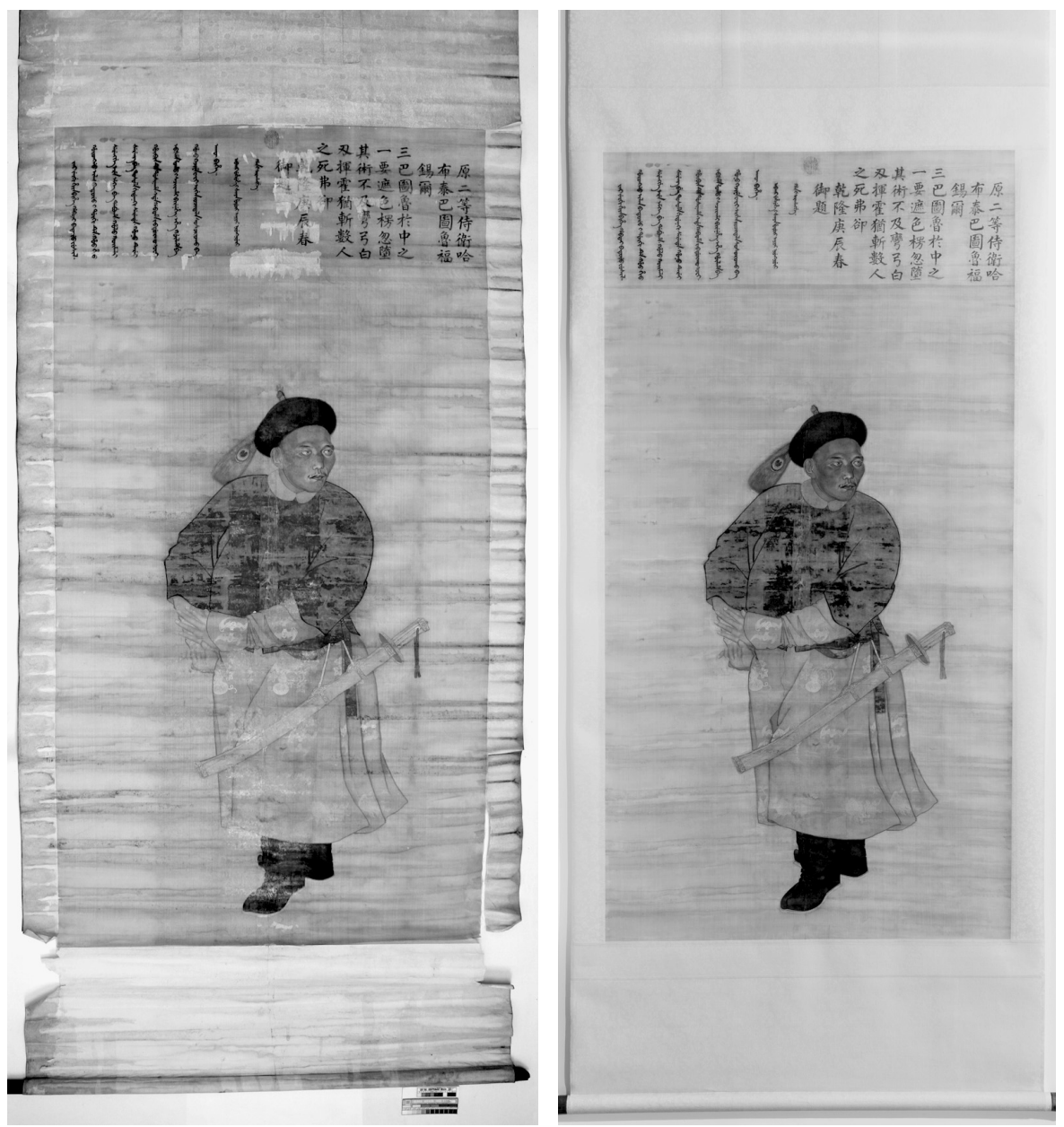

Figs. 8 and 9. Fusil's portrait before and after the restoration (C) State Hermitage Museum

Qianlong's eulogy on the second scroll (ref. No. VF 2819) is dedicated to habtai baturu (skilled warrior) ${ }^{11}$ Fusil (Chinese habutai batulu Fusier) of the Manchu Boarded Yellow Banner. ${ }^{12}$

The two stanzas of the Manchu text have initial alliteration, the first one beginning with $h$, the second with $e$.

\footnotetext{
${ }^{11}$ Hartmuth Walravens suggested translating habtai baturu as "der Fähige Bogenschütze" (WALRAVENS 2013: 150).

${ }^{12}$ WALRAVENS 2013: 150-151; BÜGENER 2015: 360-362.
} 
The Chinese text is written in four-syllable lines with caesuras in their middle and contains expressions borrowed from classical writings. For example, baidao 白刃 "white blade" is common in the novel "Three Kingdoms" (SGYYi, ch.6), the Song poems and the "Tang Anthology (QTSh, j.866); huihuo 揮霍 "to fly up- and downwards (about a sword)" can be found in the Song encyclopedia "Taiping yuelan", in "Taiping guangji" and "Tang Anthology”; fuque 弗卻 “to keep one's ground”, in “Meng-zi” (MZ, ch. 13).

Transliteration of the Manchu text:

jai jergi hiya bihe habtai baturu Fusil.

horonggo ilan baturu-i dorgi de

hoo hio serengge ere emke be dabuha

holo kûmali šereng be tosome gidanaki serede.

hono terei hûbin de dosinaha

ede gabtame jabdurakû ofi.

ebšeme loho-i sacirahai birenehe

ehe hûlha be hono kejine wafi.

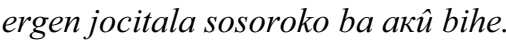

Abkai wehiyehe-i šanyan muduri aniyai

niyengniyeri han-i arahangge

\section{Translation from Manchu:}

Second-rank Imperial bodyguard habtaibaturu Fusil

Of the three experienced warriors

he is considered the bravest.

When he was about to attack treacherous Sheren,

he was ambushed.

Having no time to use his bow,

he fearlessly attacked (the enemy) with his sword,

it took him long to fight the evil enemy, but he killed him.

Not even once did he retreat.

Written by the Emperor in the spring of the White Dragon year of Abkai wehiyehe.

\section{Chinese text:}

原二等侍衛哈布泰巴圖魯福錫爾 三巴圖魯

於中之一

要遮色楞

忽墮其術

不及彎弓

白刃揮霍

猶斬數人

之死弗卻

乾隆庚辰春御題

Translation from Chinese:

Second-rank Imperial bodyguard habtaibaturu Fusil

Three brave warriors,

He was one of them.

When Seren was to be stopped in his path,

That one suddenly crushed his plans.

He had no time to use his bow,

And his naked blade started flying upand downwards.

Chopping, he killed many people

And did not retreat while he stayed alive.

Written by the Emperor in the spring of the gengchen year of Qianlong. 

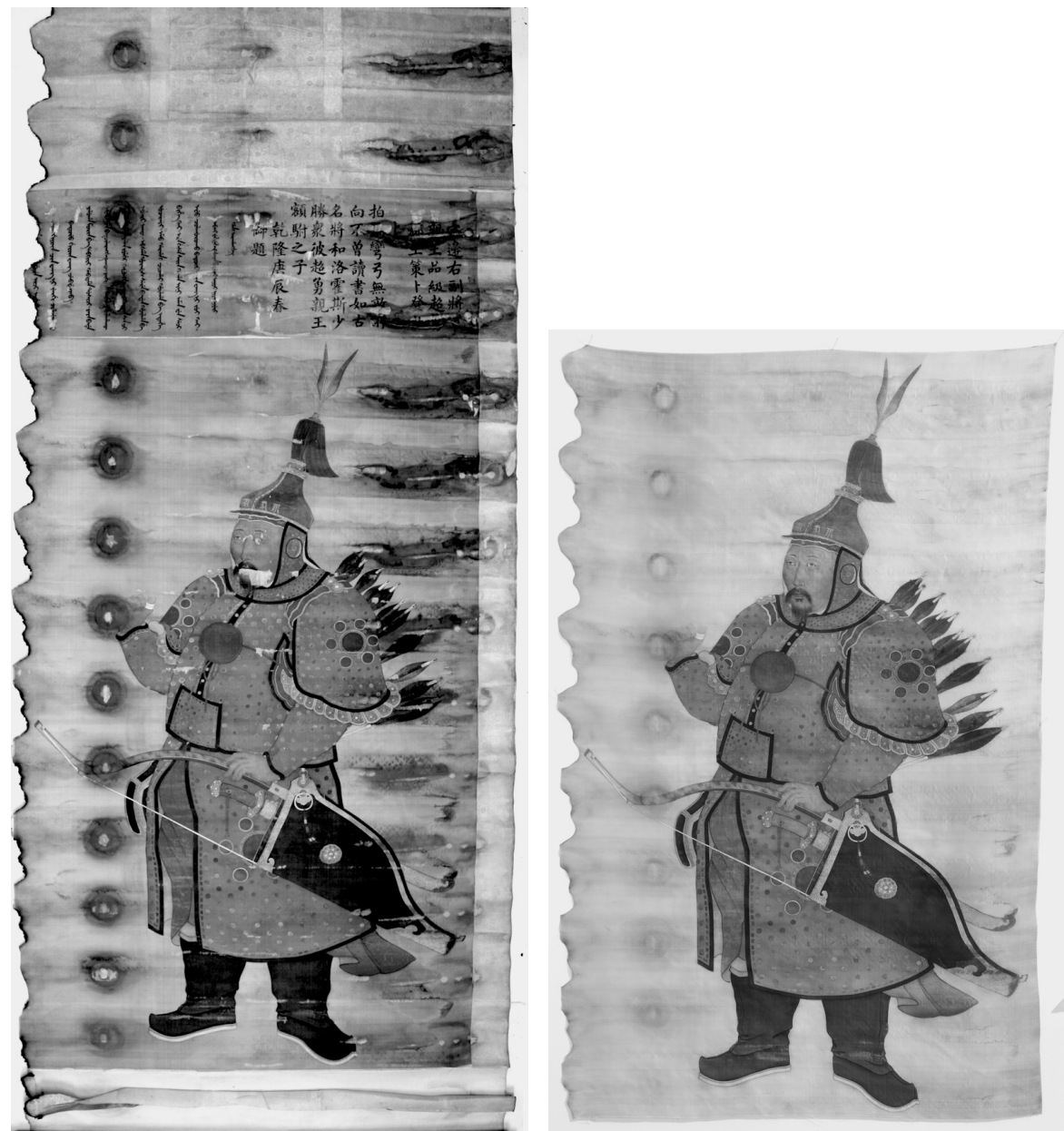

Figs. 10 and 11. Cebdenjab's portrait before and after the restoration (C) State Hermitage Museum

Qianlong's eulogy on the third scroll (ref. No. VF 2820) is dedicated to General Cebdenjab (Chinese Cebudengzhabu) (1705-1782), KhalkhaMongol of the Bordjigit clan. His father had been married to a Qing princess. In 1755, he won his spoors during the Davatchi and Amursana crackdown, and in 1758, took part in the battle of Horgos. In 1771-1773, he remained the ruler of Khalkha. ${ }^{13}$

\footnotetext{
${ }^{13}$ WALRAVENS 2013: 136-137; BÜGENER 2015: 332-335.
} 

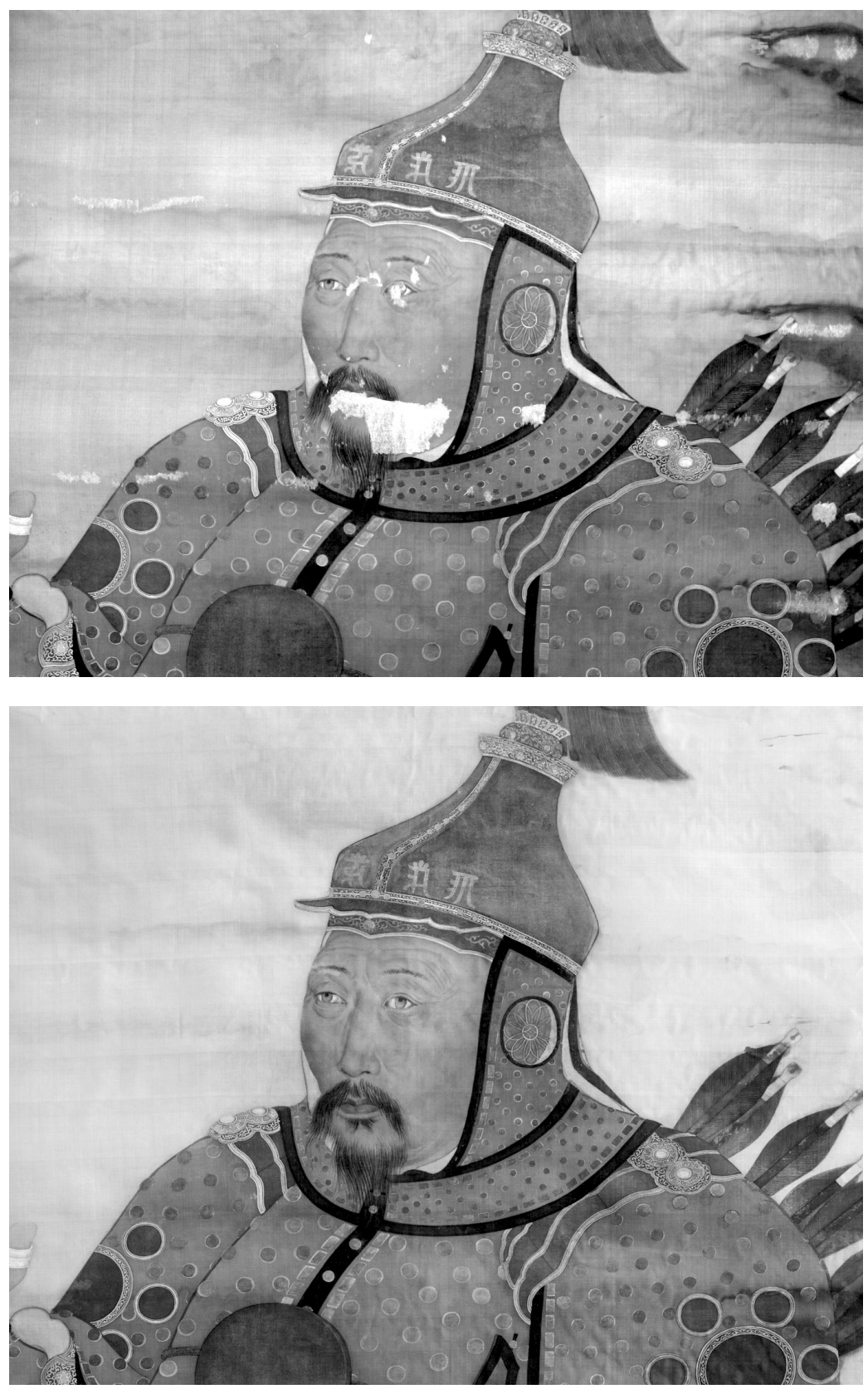

Figs. 12 and 13. A fragment of Cebdenjab's portrait before and after the restoration (C) State Hermitage Museum 
The two stanzas of the Manchu text have initial alliteration, the first one beginning with $y a$, the second with $e$.

The Chinese text written in four-character lines with caesuras in their middle contains the following expressions borrowed from classical writings: yuzhan 猶斬 "to chop" encountered in the Song encyclopedia "Taiping yuelan" (TPYL, section bubo, ch. 6); fuque 弗卻 “to keep one's ground", in “Meng-zi”; paima 拍馬 “to hit a horse with a whip" is common in the novel “Three Kingdoms” 三国演议; expressions suoxiang 所向 “on his way”, gu ming jiang 古名將 “great General of the ancient times”; chaoyong 超勇 "exceptional courage", in "History of Three Kingdoms" 三国志. The Chinese text also clearly indicates Cebdenjab's relation with the Royal family: his father was an $e f u$, i.e. the husband of the Emperor's sevenths daughter.

\section{Transliteration of the Manchu text:}

Jecen be toktobure ici ergi aisilara jiyanggiyûn cin wang-ni jergi colgoroko baturu giyûn wang Cebdenjab:

yaluha morin be dabkifi gabtame dosici yaya bade afara de bakcilarangge ak $\hat{u}$ yargiyan-i bithe hûlahakû niyalma bime. yala julgei gebungge jiyanggiyûn sa ci eberi akû ebšeme horgos sere bade hûlha be ucarafi emu gargan-i coohai hûlha be etehe bihe kai. ere gese sain haha ini ama we seci. efu colgoroko baturu cing wang-ni jui ka Abkai wehiyehe-i šanyan muduri aniyai niyengniyeri han-i arahangge

\section{Chinese text:}

定邊右副將軍親王品級超勇郡 王策卜登扎卜

拍馬彎弓
無敵所向
不曾讀書
如古名將
和洛霍斯
少勝眾彼
超勇親王
額駙之子
乾隆庚辰春御題

\section{Translation from Manchu:}

Right-flank General of the qingwang rank, a prominent hero, junwang Cebdenjab

He had no equals in various battles when he advanced shooting from his horse on the move.

He was not someone reading true histories,

\section{Translation from Chinese:}

Vice-General of the established borders bearing the qingwang rank, a prominent hero, junwang Cebdenjab

He rode his horse and drew his bow, and there were no enemies on his path.

He never read books, 
Really, he was comparable with

Like Generals of the past.

Generals of the past.

During a forced [march] he met robbers In Horgos, at a place called Horgos.

When he attacked, shooting while

He defeated enemies having small forces. riding his horse, he defeated a gang of armed bandits.

If this worthy man were asked, who his For his heroics, he was granted the title father was, of tzinvan.

He would reply: "I am a son of the

He was the son of an efu.

Emperor's son-in-law, a prominent qinwang's hero".

Written by the Emperor in the spring of the White Dragon year of Abkai wehiyehe.

Written by the Emperor in the spring of the gengchen year of Qianlong.

Qianlong's eulogy on the fourth scroll (ref. No. VF 2821) dated of 1760 is dedicated to General Bolbunca of the Aola clan, serving with the ManchuSolon Blue Boarded Banner. ${ }^{14}$

The two stanzas, four lines in each, of the Manchurian text have initial alliteration, the first one beginning with $u$, the second with $d$.

The Chinese text written in four-character lines with caesuras following the second character follows the regular Chinese model. While the Manchu text is devoid of any hidden meanings and perfectly clear, its Chinese counterpart contains a few allusions to classical writings. For instance, jueshuo 翣 䤼 "vivid (strong) in old age" can be found in the Tang dynasty "Yi wen lei jui" _ "Collection of diverse from art and literature" (YWLJ, j. 18, section "About men") and in Ma Yuan's biography (14 BC-AD 49); he lived in the time of the Han dynasty and was a famous military chieftain revered by the Manchus for his fidelity to the throne and care about his soldiers in the field. The word jubuo 巨擘 “leader" was first used by Zhu Xi in his commentary upon “Meng-zi” (MZZZh, ch.10), while wan wu shi li gong 輓五石力弓 is often there in the Song encyclopedia “Taiping yuelan” 太平御覽. The expression shazei 殺賊 “to kill bandits" is common in the novel "Three Kingdoms" 三國演義.

\footnotetext{
${ }^{14}$ WALRAVENS 2013: 138-140; BÜGENER 2015: 339-341.
} 

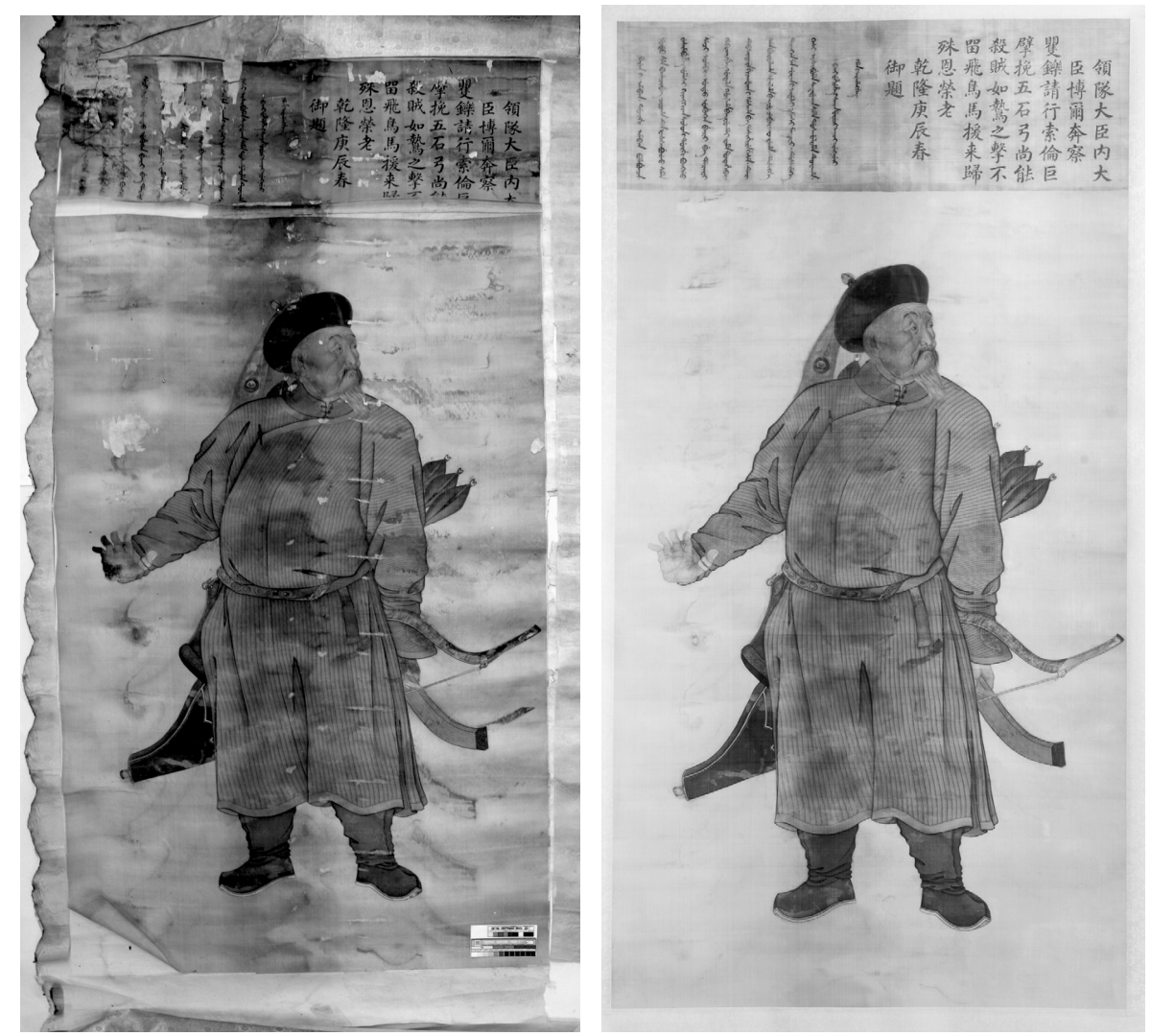

Figs. 14 and 15. Bolbunca's portrait before and after the restoration (C) State Hermitage Museum

Transliteration of the Manchu text:

Meyen-i amban dorgi amban Bolbunca

udu bahacibe cooha de faššabureo seme wesimbuhe umesi kiyangkiyan solon-i dorgi bolgo deci ombi udu uheken beri be darafi gabtacibe

utala hûlha be fuhali wame mutehebi:

debsitere giyahûn-i gasha be dasihire gese

der seme burulaha hûlha be funceburakû waha.

derengge darangga Ma Yuwan-i adali amasi marifi. desereke kesi isibume sakdaka seme dosholome tuwaha:

Abkai wehiyehe-i sanyan muduri aniyai niyengniyeri han-i arahangge
Chinese text:

领队大臣内大臣博而奔察 翟䤼請行

索倫巨擘

輓五石弓

尚能殺賊

如驇之擊

不留飛鳥

馬援來歸

殊恩榮老

乾隆庚辰春御題 

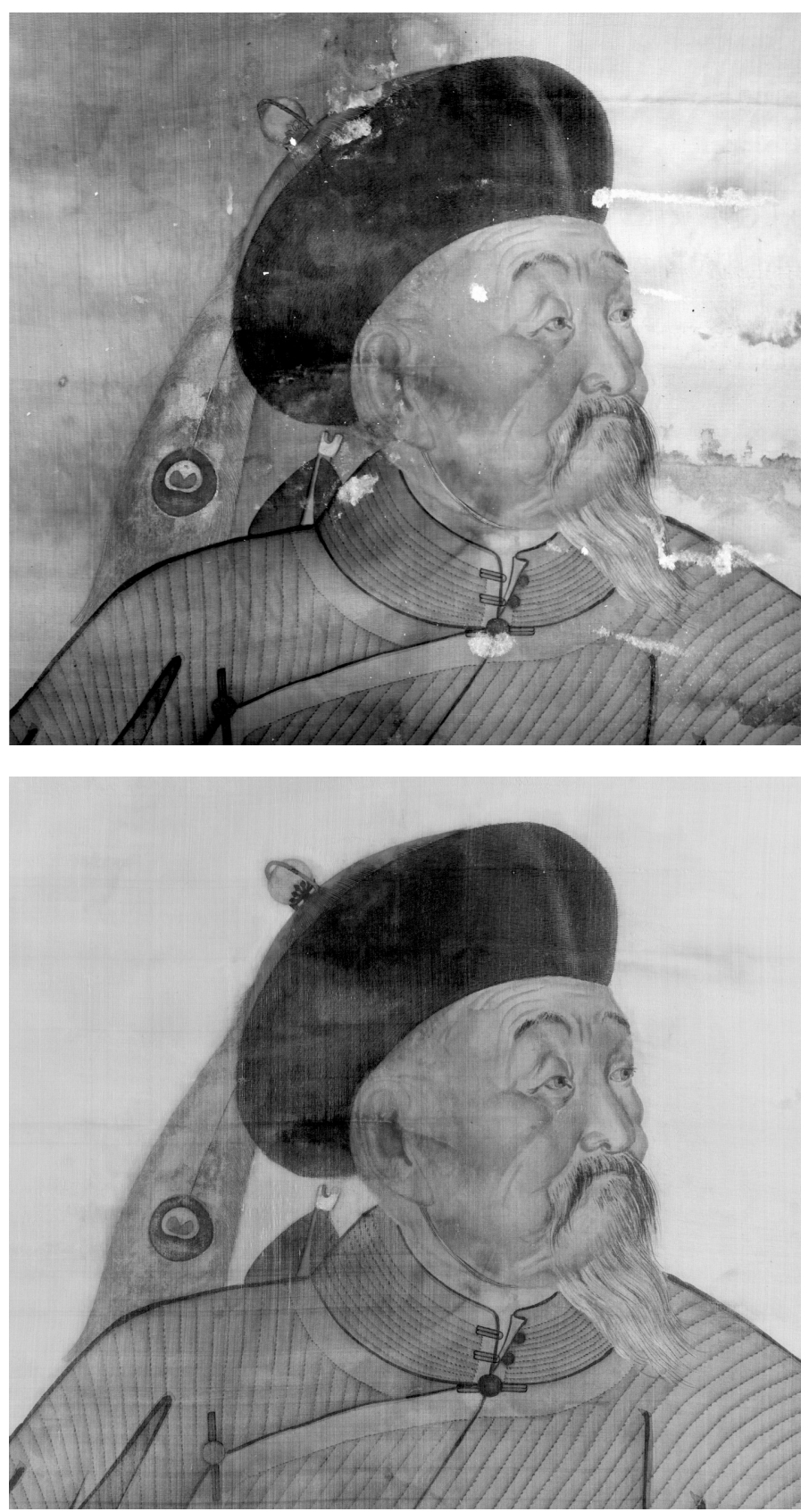

Figs. 16 and 17. A fragment of Bolbunca's portrait before and after the restoration (C) State Hermitage Museum 

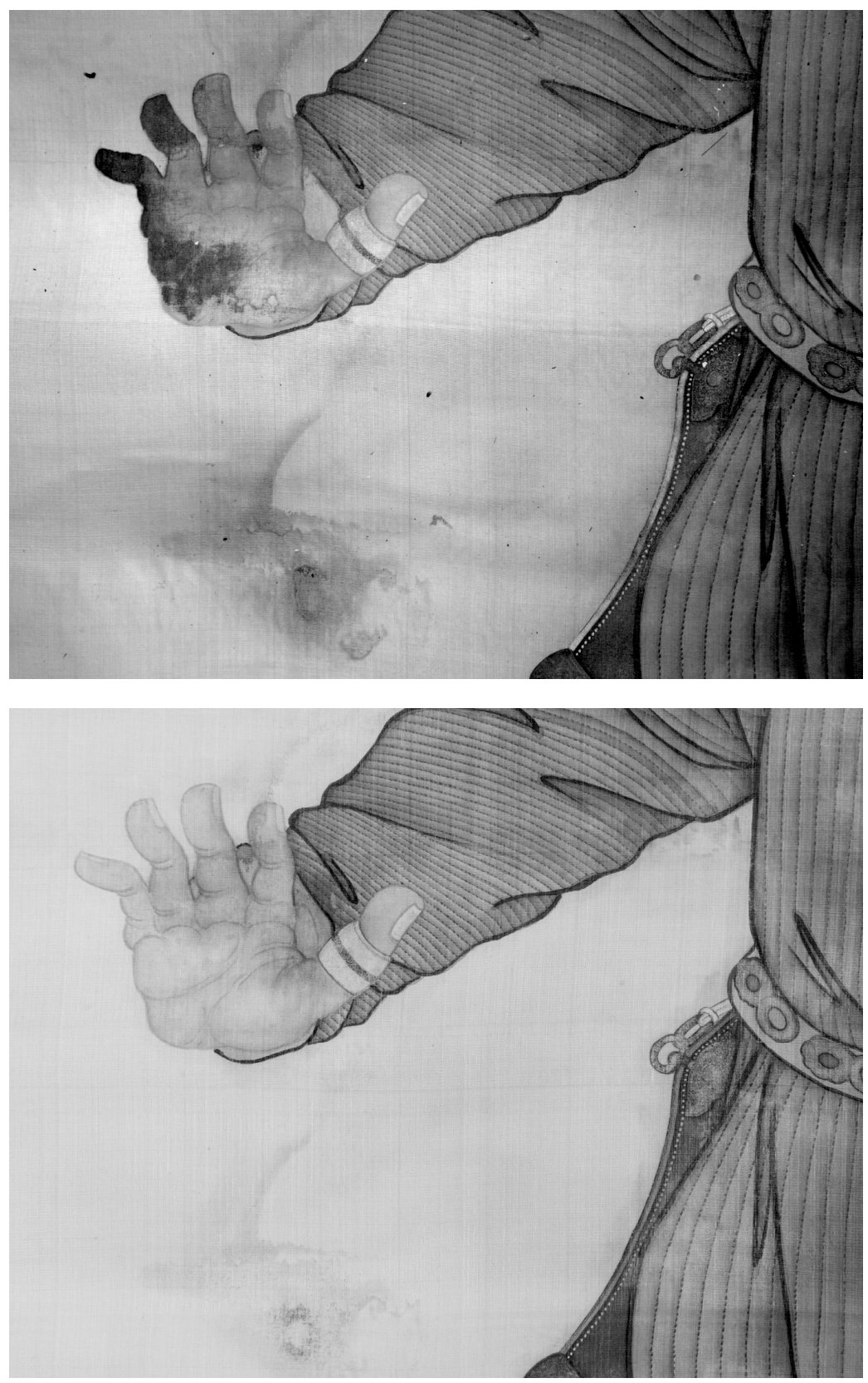

Figs. 18 and 19. A fragment of Bolbunca's portrait before and after the restoration (C) State Hermitage Museum 


\section{Translation from Manchu:}

Brigade General Bolbunca commanding the palace bodyguards.

Whenever there was an occasion, he desired to fight.

He was the bravest leader of the Solons.

He could, shooting from a poorly drawn bow,

kill a lot of bandits.

Like a bird waving its wings,

He spared no effort killing bandits about to run.

Like Ma Yuan, he returned home in respect and glory,

His old age was marked with limitless gratitude and honor.

Written by the Emperor in the spring of the White Dragon year of Abkai wehiyehe.

\section{Translation from Chinese:}

Brigade General Bolbunca commanding the palace bodyguards.

Vivid in his old age, he looked for fight.

He was the leader of the Solons.

Using five heavy bows one after another,

He could kill bandits.

Attacking like a bird of prey,

He left no [other] flying birds alive.

[He] returned home like Ma Yuan.

And deserved respect and honor in his old age.

Written by the Emperor in the spring of the gengchen year of Qianlong.

The fifth scroll from the State Hermitage collection presently undergoes restoration, but we have gained access to this portrait (according to WALRAVENS 2013: 135, its old ref. No. I D 22221). It represents a warrior wearing a winter yellowish-brown robe and a checkered green apron over it. Over the apron, on the waist level, there is a lily bandolier with ten sections and a brown powder flask. Behind his back, there is a saber, its sheath fixed to his belt. His footwear consists of winter boots with thick soles. On his head, he wears a round uniform hat with sable edging and rank distinctions: a coral sphere on its top and a peacock feather with one eye (kongqiaoling). With both hands, he is holding a musket on his left shoulder. The badly damaged text reads that the portrait depicts the commandant of town Datong in the Shangxi province, Second-rank General bardan baturu (proud hero) ${ }^{15}$ Guwandase (Chinese Guandase). The publication of an archival German photo and the full text of the eulogy made it possible to restore the fragments missing from the scroll. ${ }^{16}$

${ }^{15}$ Hartmuth Walravens suggested translating bardan baturu as "der Stolze Held" (WALRAVENS 2013: 157).

${ }^{16}$ WALRAVENS 2013: 157-158. 

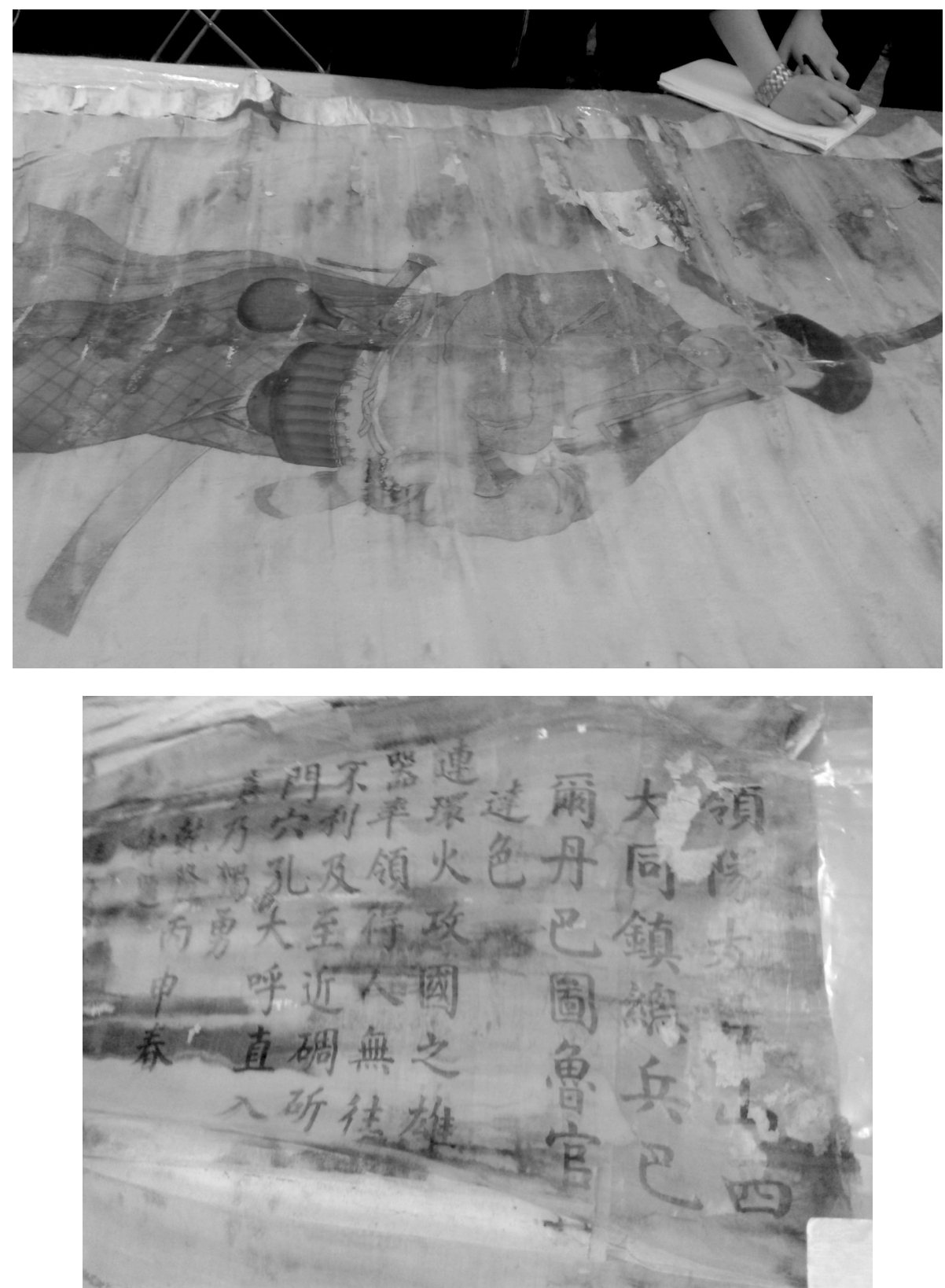

Fig. 20. Guwandase's portrait on the restoration table.

Fig. 21. A fragment of the Chinese text dedicated to Guwandase prior to its restoration (C) State Hermitage Museum 
The Manchu text is split into two stanzas with the first line starting with $i$, the second one, with $t$. The Chinese text contains words and expressions borrowed from classical compositions, e.g. lianhuan 連環 “inseparable unity, chain" frequent in the novel "Voyage to the West"; huogong 火攻 “attack with fire, shelling" can be found in "Collection of diverse from art and literature" (YWLJ, j. 80) and is common in the novel "Three Kingdoms"; shuailing 率領 "to lead, to head" can be encountered in the novels "Journey to the West", “Three Kingdoms", and "Jin ping mei”; xuekong 穴孔 "hole” was used in "Taiping yuelan" (TPYL, j. 17); duyong 獨勇 "lonesome hero" in "Taiping yuelan" (TPYL, j. 75).

\section{Transliteration of the Manchu text:}

meyen-i amban Šansi-i Datung-ni uheri kadalara da bardan baturu Guwandase

ibereleme miyoocalame afarangge.

inu musei ferguwecuke agūra seci ombi.

imbe meyen gaifi yabubuhangge acanaha of $i$

isinaha bade gemu tusa arahabi.

tereci yerutu de hanci latunafi.

tere duka be sacime sangga araha.

tede den jilgan-i kaicame dosika ofi.

terei emhuleme baturulaha be saišaha:

Abkai wehiyehe-i fulgiyan bonio aniya niyengniyeri

Han-i arahangge

\section{Chinese text:}

領隊大臣山西大同鎮總兵 把爾丹巴圖魯官達色

連環火攻

國之雄器

率領得人

無往不利

及至近碉

斫門穴孔

大呼真人

喜乃獨勇

乾隆丙申春

御題

\section{Translation from Manchu:}

Brigade General, Second-rank General bardan baturu Guwandase of [town] Datong, [province] of Shangxi

The one who attacked and advanced, shot his rifle,

That one truly was our great weapon.

Leading his troops, he was dispatched to follow [the enemy]

Wherever he was, he always helped,

\section{Translation from Chinese:}

Brigade General military commandant of [town] Datong, [province] of Shangxi bardan batulu Guandase

He advanced and attacked, and shot his rifle.

He was called the great weapon of our country.

He led his troops and successfully attacked.

In all places, he was successful. 
When he approached and stormed a stone house,

He chopped a hole in the door with his ax making a passage,

He burst inside with a loud shriek.

[His] bravery is praiseworthy.

Written by the Emperor in the spring of the Red Monkey year of Abkai wehiyehehe.
When he approached and attacked a tower,

He chopped the door and made a hole,

and burst inside with a loud shriek.

This is why his surprising courage should be celebrated.

Written by the Emperor in the spring of the bingjia year of Qianlong.

Unlike the eulogies accompanying the previous four portraits, this text is dated of 1776. It was written after the second Jinchuan campaign (i.e. suppressing the Sichuan rebellion of 1771-1776) which attributes the Guwandase portrait to the second series of those intended for the Ziguang'ge Hall of Purple Glaze. Military chieftains Yeotun, Fusil, Cebdenjab, and Bolbunca had fought in the first campaign against Eastern Turkestan (in 1755-1757), so their portraits belonged to the first series of portrait scrolls with the eulogies dated of 1760 .

The analysis of the eulogies by Emperor Qianlong shows that they reflected the poetical rules of their corresponding languages. Manchu texts followed the Manchu canon presuming initial alliteration, while those written in Chinese observed the rule requiring a four-syllable line with a caesure following the second word. They are written in accordance with the rules of Chinese classical ode. However, the most essential feature of the eulogies in Chinese is Qianlong's allusions to Chinese classics, which was typical for Chinese traditional poetry. The eulogies accompanying the five portraits kept in the State Hermitage make it possible to define those literary and historical sources which were used by Qianlong. Among them, there were the Song encyclopedia “Taiping yuelan”太平御覽, the Song collection of stories “Taiping guangji” 太平廣記, “History of Three Kingdoms” 三国志, “Collection of commentaries to Meng-zi” 孟子集注, and the "Tang Anthology” 全唐詩, novels “Three Kingdoms” 三國演義, “Journey to the West” 西游記, i.e. compositions of the Ming and Song periods well known at the Manchu court. ${ }^{17}$ No hints at Chinese texts have been traced in the Manchu version, which leads to the conclusion that Manchu eulogies were not straightforward translations from Chinese (or vice versa): these versions

\footnotetext{
${ }^{17}$ DURRANT 1979.
} 
strictly followed the poetic rules of their languages thus actually becoming two variants of the same topic.

The restoration and conservation of the portrait scrolls conducted at the State Hermitage Laboratory for scholarly restoration of fabrics and watercolors yielded fantastic results: there have been revealed artistic peculiarities of the portraits and identified the people represented in them. It is therefore possible to say that presently the State Hermitage has five portraits (of military chieftains Yeotun, Fusil, Cebdenjab, Bolbunca and Guwandase), originally from the Peking Hall of Purple Glaze Ziguang-ge which had been brought to Germany in the early 20th c., and later, after 1945, - over to the USSR.

\section{References}

BüGENER, Annette 2015: Die Heldengalerie des Qianlong-Kaisers. Ein Beitrag zur chinesischen Porträtmalerei im 18. Jahrhundert. Frankfurt am Main: Peter Lang GmbH (Europäische Hochschulschriften, Reihe XXVIII. Kunstgeschichte. Bd. 441).

DurRanT, Stephen 1979: "Sino-Manchu Translations at the Mukden Court". Journal of American Oriental Society, vol. 1, no. 4, 653-661.

MAYERS, William F. 1886: The Chinese government. A manual of Chinese titles, categorically arranged and explained, with an appendix. 2nd ed. Shanghai, Hong Kong, Yokohama: Kelly \& Walsh, Ltd.

MZJZ - Mengzi jizhu 孟子集注 [Collection of commentaries to "Mengzi”]. Chinese Text Project. URL:http://ctext.org/mengzi.

PANG T.A. and PCHELIN N.G. 2011: "Portrety vydaiushchikhsia voenachal'nikov perioda pravleniia imperatora Tsian'luna iz kollektsii Gosudarstvennogo Ermitazha" [Portraits of meritorious officers from the collection of the State Hermitage Museum]. Pis'mennye pamiatniki Vostoka [Written monuments of Orient], 2(15), 262-278.

PANG T.A. and PCHELIN N.G. 2016: "Portrety tsynskikh voenachal'nikov iz kollekcii Gosudarstvennogo Ermitazha: restavratsyia svitkov i novoe prochtenie tekstov" [Portraits of meritorious officers from the collection of the State Hermitage Museum: restoration of scrolls and revised reading of the texts]. Pis'mennye pamiatniki Vostoka, T. 13, No, 4(27), 74-90.

PANG T.A. 2015: "Portraits of the Qing meritorious generals in the Saint-Petersburg museums". In: The Fifth International Symposium of Ancient Ethnic Minority Documents of China. Proceedings. Yinchuan: Beifang University of Nationalities, 180-181.

PANG T.A. 2016: "Stikhi Tsian'luna na portretah vydaiushchikhsia generalov iz kollekcii Ermitazha" [The Qianlong emperor poems to the portraits of meritorious officers in the Hermitage museum]. In: Problemy literatur Dal'nego Vostoka [Issues of the far Eastern Literature. The 7th International conference, June 29 - July 3 2016]. Saint-Petersburg: Izdatel'stvo "Studia NP-Print", vol. 1, 473-481. 
QTSh - Quan Tang shi 全唐詩 [Anthology of the Tang dynasty poems]. Chinese Text Project. URL:http://ctext.org/quantanshi.

$S G Y Y$ - Sanguo yanyi 三國演義 [The Romance of Three kingdoms]. Chinese Text Project. URL:http://ctext.org.

TPGJ - Taiping guangji 太平廣記 [Complete records of the Taiping years]. Chinese Text Project. URL:http://ctext.org.

TPYL - Taiping yuelan 太平御覽 [Imperially approved collection of the Taiping years]. Chinese Text Project. URL:http://ctext.org.

WALRAVENS, Hartmut 2013: "Die ehemalige Sammlung von Porträts verdienter Offiziere der Feldzüge des Qianlong-Kaiseers (China, 18. Jahrhundert)”. Baessler-Archive, Bd. 61, $125-166$.

YWLJ - Yi wen lei jui 藝文類聚 (Various collection on art and literature). Chinese Text Project. URL:http://ctext.org/yiweileiju. 